\title{
Use of Biotechnological Preparations in Pig Breeding
}

\author{
Kovaleva Olga \\ Professor of Ecology and Environmental Management \\ Department \\ Northern Trans-Ural State Agricultural University, \\ 625003, Tyumen, Russia, Respubliki str. 7, e-mail: \\ lemur.84@mail.ru
}

\author{
Sannikova Natalia \\ Professor of Ecology and Environmental Management \\ Department \\ Northern Trans-Ural State Agricultural University, \\ 625003, Tyumen, Russia, Respubliki str. 7, \\ e-mail: sannikova-nv7@bk.ru
}

\begin{abstract}
Biotechnological processes cover not only biological safety, but also environmental, economic, technological and food security. A special place in the system for adequate feeding of animals becomes preparing food for feeding and especially ensuring the needs of animals with all necessary nutrients and bioactive substances. Received nutrients in the process of digestion are converted into more simple, soluble compounds with their subsequent absorption into the blood and the use of the synthesis of complex organic substances of the body. But more than one third of organic matter is not digested in the digestive tract of animals, so reducing these losses by several percent by introducing biotech products into animal rations makes it possible to increase products by $15.3 \%$ and thereby reduce the cost of production by $15 \%$.
\end{abstract}

Keywords- biotechnological process, nutrient materials, product, diet.

\section{INTRODUCTION}

At present, it is already impossible to abandon the use of biotechnology in the production of livestock products. The level of production and the cost of pork by $70-75 \%$ are determined by the cost of feed and their preparation. Considering the problem of creating a fodder base for livestock, it is noted that its effectiveness depends on the balanced diet for mineral substances, supplements, medicines, etc. Feed components of the diet are selected according to the principle of compatibility, digestibility and compensation, on demand at the appropriate stage of cultivation [15].

The availability of nutrients from plant feed can be improved by adding biotech products to feed, dozens of which pass through various stages of legislative approval each year, for example, biological emulsifiers, which are not currently well understood. Bioemulsifiers are designed to replenish the young, temporary, age-related deficiency of bile secretion. By their emulsifying properties they significantly exceed bile. In this case, the size of the micelles formed in the presence of the bioemulsifier is much smaller, and the smaller the micelles, the better the assimilation of nutrients [1]. More than one-third of the organic matter is not digested in the digestive tract of animals [5], so reducing these losses by at least a few percent due to the introduction of biologically active substances into the rations will allow obtaining additional products, and hence lowering its cost price.

\section{RESULTS AND DISCUSSION}

In order to study the scientific and practical significance of using one of these biotechnological preparations in the rations of young pigs in the training and experimental farm of Tyumen State Agricultural Academy, scientific and economic and physiological experiment was carried out with young pigs of large white breeds, the scheme of the studies is presented in Table 1.

TABLE I. THE SCHEME OF EXPERIENCE

\begin{tabular}{|l|c|c|l|}
\hline Group of animals & $\begin{array}{c}\text { Age, } \\
\text { mon. }\end{array}$ & $\begin{array}{c}\text { Quantity } \\
\text { of animals }\end{array}$ & \multicolumn{1}{|c|}{ Feeding characteristic } \\
\hline control & $4-8$ & 10 & $\begin{array}{l}\text { cereal mixture (wheat- 32, } \\
\text { oats -44, peas -24\%) }\end{array}$ \\
\hline 1 experimental & $4-8$ & 10 & $\begin{array}{l}\text { cereal mixture }+0.75 \\
\text { kg/ton "Lysoforte" }\end{array}$ \\
\hline 2 experienced & $4-8$ & 10 & $\begin{array}{l}\text { cereal mixture }+1.0 \mathrm{~kg} / \mathrm{ton} \\
\text { "Lysoforte" }\end{array}$ \\
\hline
\end{tabular}

For the scientific and economic experience, 30 piglets were selected at the age of 4 months, who were divided into 3 groups of 10 heads each. Formation of groups was carried out on the principle of analogs taking into account age, live weight, origin and state of health.

The experiment was carried out using a lipoform lipo-lipoemulsifier, manufactured by Kemin (Belgium), consisting of hydrolysed lecithin, silica, salt, ground almond shell. «Lysoforte» is used in animal feed to improve the absorption of fats and other nutrients in the feed, as well as the formation of micelles in the intestine and the normalization of the immunebiological reactivity.

The feeding of experimental animals in both experiments was carried out according to detailed feeding standards (Norms ..., 2003). Access to water was free. The conditions of keeping the animals of the compared groups were the same.

The growth rate of fattened young pigs was taken into account by monthly control weighing. Based on the data obtained, the average daily weight gain of pigs was calculated.

Against the backdrop of scientific and economic experience at the age of 8 months, three animals from each group 
underwent physiological experience to determine the digestibility of nutrients in the rations and the use of energy, nitrogen, and minerals.

During the experiment the piglets were in individual cages equipped with devices for collecting urine and feces. In the accounting period of the experiment, the given feeds, their residues were weighed daily the amount of excreted feces and urine was taken into account. For the chemical analysis, average samples of feed, residues, feces and urine were taken. The physiological state was judged by changes in hematological and biochemical blood parameters. The analysis was carried out in the Tyumen Oblast Veterinary Station for the following parameters: total protein, reserve alkali, calcium, phosphorus, protein and its fractions, erythrocytes and leukocytes.

To determine the effect of different amounts of bioemulsifier in the ration on the meat productivity of pigs, at the end of the scientific and economic experience, control animals were slaughtered at the age of 8 months and 3 heads in each group.

For a more detailed characteristics of the processes of meat formation, each carcass was boned, followed by the determination of the amount of pulp, fat and bones in it medium samples of meat and bacon were taken for chemical analysis.

The data obtained in the studies were processed biometrically on a personal computer. The results of the studies were considered highly reliable at $\mathrm{P}<0.001$ and significant at $\mathrm{P}$ $<0.01$ and $\mathrm{P}<0.05$.

The maximum productivity of pigs is achieved only when proper care and maintenance are combined with adequate and full feeding of animals during all periods of their life [3]. A fullfledged feeding of pigs should ensure the optimal body's need for energy, protein, essential amino acids, minerals and vitamins, taking into account their age, physiological condition, productivity, breed and conditions [8].

To obtain high increments from young pigs, it is necessary to provide them with full-value feeds [12]. To meet the needs of young pigs in sodium and chlorine, diets in the amount of $0.5 \%$ by weight were added to the rations. On salt-free diets, animals poorly digest the protein part of the feed, lag behind in growth and development.

One of the important factors in the feeding of pigs is its overall nutritional and energy concentration in dry matter [10]. The total nutritional value of the rations, calculated taking into account the digestibility factors, was $2.70-2.75$ energy feed units, 27.02-27.49 MJ of exchange energy from 5 to 6 months of age, which was within the norm.

Pig satisfy the energy demand consuming $60 \%$ carbohydrates. Carbohydrates account for $75 \%$ of the dry matter of most plant foods. The rations of the piglets of the control group contained crude fiber - $138.81 \mathrm{~g}, 1$ experimental 141.24 and 2 experimental - 140.02 , or $6.86 \%$ of dry matter, and also - 93.21g of digested protein per 1EEK, in 1 experimental - 95.17; in 2 experimental $-93.72 \mathrm{~g}$. The diet of the control group contained - lysine $13.05 \mathrm{~g}$, methionine + cystine $-8.45 \mathrm{~g}$; in the 1 experimental -13.28 and 8.60 ; in the 2nd trial group, 13.17 and 8.52 , respectively.
The calcium content in the test groups was in the range of 17.13 - $17.21 \mathrm{~g}$, phosphorus - 14.17 - $14.34 \mathrm{~g}$, the ratio of calcium to phosphorus was 1.2: 1 . The iron content of $133 \mathrm{mg}$, copper - $12.64 \mathrm{mg}$, zinc - $82.22 \mathrm{mg}$, manganese - $93.52 \mathrm{mg}$; in animals of 1 experimental group, $135.33 ; 12.86 ; 83.66 ; 95.16$; 2 of the experimental $134.16 ; 12.75 ; 82.94 ; 94,34$, respectively, which corresponds to the norm of feeding.

The need for animals in vitamins depends on their age, the level of productivity, the technology of content, the composition of the diet and the availability of vitamins in feeds [9].

As a result, the piglets of the control group consumed dry pigments of the control group: vitamin E - $100.38 \mathrm{mg}, \mathrm{B} 1$ $12.44 \mathrm{mg}, \mathrm{B} 3-24.66 \mathrm{mg}, \mathrm{B} 5-82.37 \mathrm{mg} ; 1$ of the experimental group $102.13 ; 12.65 ; 25.09 ; 83.81,2$ experimental 101.25; $12.54 ; 24.87 ; 83.09$ respectively.

Animal diets from 7 to 8 months of age in the control group contained $93.06 \mathrm{~g}$ digestible protein per $1 \mathrm{CU}$, in 1 pilot -95.18 ; in 2 experimental $-93.95 \mathrm{~g}$. In the dry matter of the diet of the animals of the control group, lysine - $18.58 \mathrm{~g}$, methionine + cystine $-12.03 \mathrm{~g}$; accordingly in 1 experimental $-19,61 ; 12.69$, in the 2 experimental $-19.44 ; 12.58 \mathrm{~g}$.

In the dry matter of the diet of the gum pigs control group contained calcium - $0.83 \%$, phosphorus - $0.75 \% ; 1$ experimental group and 2 experimental group - 0.80 and 0.73 , respectively.

The rations of the animals of the control group contained (mg): iron - 189.34; copper - 17.99; zinc - 117.05; manganese 133.14, in 1 experimental group - 199.78; 18.99; 123.51; 140.49 , in the 2 experimental - 198.05; 18.82; 122.43; 139.26 respectively.

Animals of the control group received vitamin E - 142.89 $\mathrm{mg}$; B1 - $17.71 \mathrm{mg}, \mathrm{B} 3-35.10 \mathrm{mg}$, B5 - $117.26 \mathrm{mg} ; 1$ of the experimental group 150.78; 18.68; 37.04; 123.74, 2 experienced $149.47 ; 18.52 ; 36.71 ; 122.66$ respectively.

Thus, rations for fattening young animals completely provided the need of experimental animals in basic nutrients not only for maintaining life, but also for the synthesis of products.

Live weight and average daily increments are the total indices of the increase in body weight of animals that serve as indicators of their overall development, economic and physiological precocity.

Control over the change in the live weight of animals throughout the scientific and economic experience was carried out by individual monthly weighing (Table 2).

From the data given, it can be concluded that the average live weight of the pigs, when set for the experiment, was almost the same and amounted to $35.9-36.0 \mathrm{~kg}$.

From the age of 5 months, there is a tendency to increase the live weight of the experimental groups. Thus, at this age, the pigs of the 2 nd test group-58.7 kg-had the largest live weight, which is $11.2 \%$ more than in the control animals, and also by $4.3 \%$ than in the 2 experimental groups. At the end of the experiment, the difference in live weight in favor of the 1 
experimental group was $9.7 \%$ compared to the control and $4.6 \%$ with the 2 test group.

TABLE II. DYNAMICS OF LIVE WEIGHT AND AVERAGE DAILY GAINS OF GILT, $\bar{X} \pm \mathbf{S} \bar{X}$

\begin{tabular}{|c|c|c|c|}
\hline \multirow{2}{*}{ Index } & \multicolumn{3}{|c|}{ Group } \\
\hline & Control & 1 experimental & 2 experimental \\
\hline \multicolumn{4}{|c|}{ I repetend } \\
\hline \multicolumn{4}{|l|}{ live weight, kg: } \\
\hline at first & $36.0 \pm 0.31$ & $35.9 \pm 0.29$ & $36.0 \pm 0.31$ \\
\hline in 5 months & $52.8 \pm 0.64$ & $58.7 \pm 0.42$ & $56.2 \pm 0.41$ \\
\hline in 6 months & $67.4 \pm 0.65$ & $73.1 \pm 0.46$ & $69.1 \pm 0.60$ \\
\hline $\begin{array}{l}\text { Average daily gain, } \\
\mathrm{g}\end{array}$ & $532 \pm 6.63$ & $631 \pm 4.46$ & $561 \pm 6.76$ \\
\hline \multicolumn{4}{|c|}{ II repetend } \\
\hline \multicolumn{4}{|l|}{ live weight, kg: } \\
\hline in 7 months & $83.2 \pm 0.81$ & $92.7 \pm 0.59$ & $88.2 \pm 0.80$ \\
\hline in 8 months & $102.1 \pm 0.87$ & $112.0 \pm 0.38$ & $106.9 \pm 0.37$ \\
\hline $\begin{array}{l}\text { Average daily gain, } \\
\text { g }\end{array}$ & $569 \pm 9.66$ & $638 \pm 7.92$ & $620 \pm 6.72$ \\
\hline \multicolumn{4}{|c|}{ in general } \\
\hline Gross increase, $\mathrm{kg}$ & 66.1 & 76.1 & 70.9 \\
\hline $\begin{array}{c}\text { Average daily gain, } \\
\text { g }\end{array}$ & $542 \pm 4.90$ & $624 \pm 2.39$ & $581 \pm 1.55$ \\
\hline
\end{tabular}

The smallest average daily increments were in the control group, the difference between them as a whole for the experiment was $15.1 \%$ compared with 1 experimental and $7.2 \%$ with 2 test group. The study of the chemical composition of animal feed and animal body shows that the basic organic substances contained in them are represented in different quantitative proportions and qualitatively differ among themselves. As a rule, the incoming nutrients in the process of digestion are converted into more simple, soluble compounds, followed by their absorption into the blood and the use of the body to synthesize complex organic substances. Therefore, the study of the process of digesting various feeds by animals is an indispensable element in assessing their nutritional value.

To determine the digestibility and use of nutrients in the rations, a physiological experiment was conducted on 9 gilts. Each animal was given an individual feed. Based on the data on the amount of nutrients consumed and allocated, the amount of digestible nutrients was calculated (Table 3).

TABLE III. AVERAGE DAILY AMOUNT OF NUTRIENTS DIGESTED BY GILT, G/HEAD $(\bar{X} \pm \mathbf{S} \bar{X})$

\begin{tabular}{|c|c|c|c|}
\hline \multirow{2}{*}{ Index } & \multicolumn{3}{|c|}{ Group } \\
\cline { 2 - 4 } & Control & 1 experimental & 2 experimental \\
\hline $\begin{array}{c}\text { dry } \\
\text { substance }\end{array}$ & $2335.47 \pm 24.52$ & $2549.76 \pm 13.48$ & $2492.93 \pm 22.55$ \\
\hline $\begin{array}{c}\text { organic } \\
\text { substance }\end{array}$ & $2060.30 \pm 3.06$ & $2239.11 \pm 9.14$ & $2186.35 \pm 20.18$ \\
\hline crude protein & $358.22 \pm 2.18$ & $386.39 \pm 1.76$ & $377.70 \pm 3.57$ \\
\hline raw fat & $54.72 \pm 0.71$ & $65.25 \pm 0.58$ & $63.13 \pm 0.58$ \\
\hline crude fiber & $85.77 \pm 4.07$ & $109.16 \pm 1.48$ & $101.62 \pm 5.39$ \\
\hline BEV & $1561.59 \pm 7.59$ & $1678.31 \pm 5.86$ & $1643.90 \pm 11.61$ \\
\hline
\end{tabular}

According to the table, it can be concluded that gilts 1 of the experimental group digested dry matter more - by $9.2 \%$, organic matter - by $8.7 \%$, crude protein - by $7.9 \%$, raw fat - by $19.2 \%$ and BEV - by $7.5 \%$ than in the control.

The same tendency to improve the digestibility of nutrients in comparison with the control is also observed in the 2nd experimental group. An important indicator of the use of nutrients by animals for feed consumption is the digestibility factors (Table 4), which represent the ratio of digested nutrients to consumed, expressed as a percentage.

TABLE IV. Nutrient Digestibility Factors, $\%(\overline{\mathbf{X}} \pm \mathbf{S} \overline{\mathbf{x}})$

\begin{tabular}{|c|c|c|c|}
\hline \multirow{2}{*}{ Index } & \multicolumn{3}{|c|}{ Group } \\
\cline { 2 - 4 } & Control & 1 experimental & $\begin{array}{c}2 \\
\text { experimental }\end{array}$ \\
\hline dry substance & $81.93 \pm 0.50$ & $83.90 \pm 0.25$ & $82.75 \pm 0.58$ \\
\hline organic substance & $83.82 \pm 0.60$ & $86.32 \pm 0.09$ & $85.02 \pm 0.61$ \\
\hline crude protein & $80.57 \pm 1.03$ & $82.35 \pm 0.30$ & $81.20 \pm 0.64$ \\
\hline raw fat & $74.52 \pm 1.47$ & $84.20 \pm 0.45$ & $82.18 \pm 0.60$ \\
\hline crude fiber & $47.33 \pm 2.60$ & $57.05 \pm 0.59$ & $53.58 \pm 2.74$ \\
\hline BEV & $88.79 \pm 0.27$ & $90.43 \pm 0.01$ & $89.35 \pm 0.45$ \\
\hline
\end{tabular}

The data analyzed indicate that the digestibility of dry and organic matter, whose digestion coefficients were higher in the pigs of the 1st test group, by 2.4 and 2.98, respectively, improved in comparison with their control analogs in the piglets of the experimental groups fed with feed supplement; \%, 2 test groups - by 1.0 and $1.4 \%$.

Animals of experimental groups also better digested crude protein, crude fat, crude fiber and BEV. Thus, in piglets of 1 experimental group, the digestibility ratio of crude protein was $2.21 \%$ more, 2 experimental $-0.78 \%$, raw fat 12.99 and $10.28 \%$ and crude fiber by 20.5 and $13.2 \%$, as well as BEV by 1.85 and $0.63 \%$, respectively, than in the piglets of the control group.

The difference between the experimental groups was the highest in digestibility ratios of crude fiber and raw fat, which was 6.08 and $2.4 \%$, respectively, in favor of 1 experimental group.

Thus, the gilt pigs of the experimental group who received $0.75 \mathrm{~kg} /$ ton in the Lysoforte diet were better able to digest raw nutrients than control animals, which served as an additional source of energy for the production of products.

The nutritional value of the diet can not be judged only from the digestibility data. It is necessary to take into account the degree of utilization by the animal organism of digestible feed substances.

One of the indicators characterizing the state of metabolism and adaptation of animals to the conditions of feeding and maintenance is the state of energy metabolism [14].

Under optimum conditions of feeding and maintenance in pigs, on average only about $30 \%$ of the total energy of the feed is used for the production of products: the deposition of protein and fat in growth [7]. The rest of the gross energy is spent for the realization of the vital functions of the body (heat production) and is lost in the process of metabolism with un- 
digested feed substances, with under-oxidized exchange products (urine) and in gaseous secretions [13].

The distribution and use of dietary energy in piglets is presented in Table 5 .

TABLE V. DISTRIBUTION AND USE OF ENERGY IN GILTS (ON AVERAGE PER DAY, MJ), $\overline{\mathrm{X}} \pm \mathrm{S} \overline{\mathrm{x}}$

\begin{tabular}{|c|c|c|c|}
\hline \multirow{2}{*}{ Index } & \multicolumn{3}{|c|}{ Group } \\
\cline { 2 - 4 } & Control & 1 experimental & 2 experimental \\
\hline $\begin{array}{c}\text { consumed VE feed, } \\
\text { MJ }\end{array}$ & $47.11 \pm 0.37$ & $49.72 \pm 0.18$ & $49.28 \pm 0.10$ \\
\hline $\begin{array}{c}\text { conversion of } \\
\text { energy, MJ }\end{array}$ & $38.68 \pm 0.05$ & $42.14 \pm 0.18$ & $41.14 \pm 0.38$ \\
\hline$\%$ from VE & $82.11 \pm 0.65$ & $84.77 \pm 0.10$ & $83.47 \pm 0.60$ \\
\hline exchange energy, MJ & $37.17 \pm 0.04$ & $40.45 \pm 0.17$ & $39.50 \pm 0.35$ \\
\hline$\%$ from VE & $78.89 \pm 0.58$ & $81.37 \pm 0.09$ & $80.15 \pm 0.54$ \\
\hline life support costs, MJ & $12.97 \pm 0.20$ & $13.69 \pm 0.41$ & $13.48 \pm 0.08$ \\
\hline $\begin{array}{c}\text { productive energy, } \\
\text { MJ }\end{array}$ & $30.62 \pm 0.16$ & $33.21 \pm 0.52$ & $32.44 \pm 0.65$ \\
\hline net energy, MJ & $6.55 \pm 0.18$ & $7.24 \pm 0.41$ & $7.06 \pm 0.65$ \\
\hline $\begin{array}{c}\text { energy of heat } \\
\text { production, MJ }\end{array}$ & $24.07 \pm 0.34$ & $25.96 \pm 0.92$ & $25.38 \pm 1.25$ \\
\hline $\begin{array}{c}\text { efficiency of using } \\
\text { the OE, \% }\end{array}$ & $17.62 \pm 0.47$ & $17.91 \pm 1.06$ & $17.87 \pm 1.60$ \\
\hline
\end{tabular}

It can be noted that the level of consumption of gross energy was maximal in piglets 1 and 2 of the experimental groups, compared to the animals in the control group by 5.5. The consumption of gross energy in the two experimental groups was less by $0.9 \%$ compared to 1 experimental group.

The animals of the experimental groups were better able to digest the resulting food and the digestible energy was significantly higher by $3.46 ; 2.46 \mathrm{MJ}$, or - by $8.9 ; 6.4 \%$.

The level of exchange energy in piglets of the control group is $8.1 \%$ reliably less than in 1 experimental group, $5.9 \%$ in 2 experimental ones.

The exchange energy as a percentage of the gross in the pigs of the 1st experimental group was 3.1\% higher than in the control group, and $1.5 \%$ higher than in the animals of the 2 nd test group. The increase in this indicator in the 2 experimental groups in comparison with the control was $1.6 \%$.

The lowest energy consumption for life support was in the control group animals - $12.97 \mathrm{MJ}$, i.e., 5.3 and 3.8\% than in gilts 1 and 2 of the experimental groups.

The piglets of the 2nd experimental group had a higher level of pure growth energy, or $0.69 \mathrm{MJ}$, or $10.5 \%$ more than the control group analogs, and $0.18 \mathrm{MJ}(2.5 \%)$ in comparison with 2 experimental group.

The effectiveness of the use of exchange energy in piglets 1 and 2 of the experimental groups by $1.6 ; 1.4 \%$ more than in the analogues of the control group. The difference between the experienced was $0.22 \%$ in favor of 1 trial group.

That is, the inclusion in the rations of pigs of the bioemulsifier "Lysofort" increased the level of consumption of gross energy and ensured more effective use of exchange energy for the growth of live weight.

No substance of biological origin is so important and has such multifaceted functions in the life of the body as protein. Proteins in the body are not deposited, so when the protein is deficient in the diet, the body begins to use functional proteins as energy sources. The balance of nitrogen characterizes the biological usefulness of feeding fodder to animals and is an indicator of the use of nitrogenous feed substances.

The results of studies on the study of nitrogen metabolism in gilts with different feeding of a bioemulsifier are presented in Table 6.

TABLE VI. Daily balance AND USE OF FeED NitRogen, $\mathrm{g}(\overline{\mathrm{X}} \pm \mathbf{S} \overline{\mathrm{x}})$

\begin{tabular}{|c|c|c|c|}
\hline \multirow{2}{*}{ Index } & \multicolumn{3}{|c|}{ Group } \\
\cline { 2 - 4 } & Control & 1 experimental & 2 experimental \\
\hline accepted with food & $71.13 \pm 0.55$ & $75.07 \pm 0.27$ & $74.42 \pm 0.16$ \\
\hline isolated in feces & $13.83 \pm 0.83$ & $13.26 \pm 0.24$ & $13.99 \pm 0.45$ \\
\hline overdone & $57.31 \pm 0.35$ & $61.54 \pm 0.28$ & $60.43 \pm 0.57$ \\
\hline isolated in urine & $31.56 \pm 1.60$ & $30.09 \pm 0.83$ & $30.74 \pm 1.03$ \\
\hline snoozed in the body & $25.74 \pm 1.70$ & $31.73 \pm 0.97$ & $29.69 \pm 1.21$ \\
\hline used, \%: & & & \\
\hline from the adopted & $36.18 \pm 2.29$ & $42.26 \pm 1.14$ & $39.90 \pm 1.64$ \\
\hline from digested & $44.90 \pm 2.89$ & $51.32 \pm 1.44$ & $49.12 \pm 1.82$ \\
\hline
\end{tabular}

The data show that animals of all groups had a positive nitrogen balance. According to the results of physiological experience, the balance of nitrogen indicates a tendency to increase the accumulation of nitrogen in the body of young test groups. Thus, the maximum nitrogen deposition ( $42.26 \mathrm{~g} /$ day) was noted in the pigs of the 1 experimental group, which is $23.3 \%$ more than in the control group and $6.4 \%$ than in the 2 test group. Piglets of the 2 test group also outperformed the analogues of the control group by the nitrogen balance by $15.3 \%$.

Animals of 1 and 2 test groups at 6.08 and $3.72 \%$ respectively used more consumed nitrogen, in comparison with the analogues of the control group. The digested nitrogen was also more efficiently used by the animals of the experimental groups and amounted to $51.32 \%$ in 1 experimental group, $49.12 \%$ in the 2 experimental group, which is 6.42 and $4.22 \%$ correspondingly higher than in the control group.

Thus, the exchange of nitrogen in young pigs for fattening is directly dependent on the incoming amount of nutrients and biologically active substances in the body. The most favorable absorption of nitrogen in the body occurs with feeding in diets of the bio-emulsifier "Lysoforte" in the amount of $0.75 \mathrm{~kg} / \mathrm{ton}$.

The digestibility and use of feed nutrients are influenced by various factors, including the level and ratio of mineral substances in the diet [6].

To assess the supply of pigs with minerals, it is necessary to know not only their total content in feeds, but also the degree of 
assimilation by the body. The use of calcium in experimental animals is presented in Table 7.

TABLE VII. DAIly BALANCE AND CALCIUM USE, G $(\overline{\mathbf{X}} \pm \mathbf{S} \overline{\mathbf{x}})$

\begin{tabular}{|c|c|c|c|}
\hline \multirow{2}{*}{ Index } & \multicolumn{3}{|c|}{ Group } \\
\cline { 2 - 4 } & Control & 1 experimental & 2 experimental \\
\hline accepted with food & $23.92 \pm 0.05$ & $24.27 \pm 0.02$ & $24.21 \pm 0.01$ \\
\hline isolated in feces & $12.77 \pm 0.35$ & $11.45 \pm 0.44$ & $12.28 \pm 0.80$ \\
\hline $\begin{array}{c}\text { isolated in urine } \\
\text { snoozed in the } \\
\text { body }\end{array}$ & $1.73 \pm 0.09$ & $1.66 \pm 0.09$ & $1.75 \pm 0.06$ \\
\hline $\begin{array}{c}\text { used,\% } \\
\text { from the adopted }\end{array}$ & $39.39 \pm 1.52$ & $45.99 \pm 1.72$ & $42.04 \pm 3.28$ \\
\hline
\end{tabular}

Inclusion of the bio-emulsifier "Lysoforte" in the rations of the piglets of the experimental groups had a significant effect on the deposition of calcium in their body, as well as the degree of use of this macronutrient from the diet. Thus, animals of all groups consumed almost the same amount of calcium - 23.9224.27 g. Calcium was more effective in animals of 1 experimental group, in the body of which $11.16 \mathrm{~g}$ of this element was reliably deposited, or $45.99 \%$ of the taken with food, which is 6.6 and $2.65 \%$ more than that of their control and 2 test groups. 8.

The balance and use of phosphorus are presented in Table

TABLE VIII. DAILY BALANCE AND USE OF PHOSPHORUS, G $(\overline{\mathbf{X}} \pm \mathbf{S} \overline{\mathbf{x}})$

\begin{tabular}{|c|c|c|c|}
\hline \multirow{2}{*}{ Index } & \multicolumn{3}{|c|}{ Group } \\
\cline { 2 - 4 } & Control & 1 experimental & 2 experimental \\
\hline accepted with food & $21.47 \pm 0.11$ & $22.23 \pm 0.05$ & $22.10 \pm 0.03$ \\
\hline isolated in feces & $11.35 \pm 0.27$ & $10.06 \pm 0.32$ & $10.99 \pm 0.65$ \\
\hline isolated in urine & $1.31 \pm 0.05$ & $1.26 \pm 0.01$ & $1.32 \pm 0.03$ \\
\hline snoozed in the body & $8.82 \pm 0.24$ & $10.91 \pm 0.30$ & $9.79 \pm 0.70$ \\
\hline $\begin{array}{c}\text { used,\% } \\
\text { from the adopted }\end{array}$ & $41.08 \pm 1.27$ & $49.07 \pm 1.37$ & $44.29 \pm 3.11$ \\
\hline
\end{tabular}

It can be noted that the use of phosphorus pigs shows the same pattern as calcium. The amount of phosphorus consumed in the experimental groups was within the normal range and amounted to $21.47-22.23$ g. In 1 test group, phosphorus was released in the feces by $11.36 \%$ less than in the control group and by $8.46 \%$ compared to the 2 experimental group. The greatest amount of phosphorus was highly reliably deposited in the animals of the 1 experimental group - $10.91 \mathrm{~g}$ or $49.07 \%$ of that taken with food, which is 7.99 and 3.21 more compared to the control group and 2 test groups, $\%$, respectively.

Thus, the inclusion of the bio-emulsifier "Lysoforte" in the rations of piglets in an amount of $0.75 \mathrm{~kg} / \mathrm{t}$ positively affects the energy metabolism and the use of nutrients in the body of experimental animals.

Blood, being the internal environment of the body, plays an exceptionally important role in its processes. Through blood, the most important property of living matter is metabolism.
Blood determines the existence of all cells of the body, and also fully reflects in their composition their vital functions for each moment. According to the morphological and biochemical properties of blood, one can judge the health of an animal, the state of metabolism and its productivity. The more changes in metabolism in the body, the stronger the change in blood.

The composition of the blood not only reflects the state of the animal, but also gives a general idea of fitness for the environment. The picture of blood allows you to observe various changes taking place in the animal's body under the influence of feeding and maintenance. Therefore, the study of hematological indicators helps to correctly understand and associate these changes with productivity.

It is known that erythrocytes and, contained in them hemoglobin, is the main mass of the formed elements of blood. With increased circulation through the organs and tissues, much more blood passes, and therefore the total surface of the erythrocytes, coming into contact with the tissues, is greatly increased at this time; this ensures the rapid fulfillment by the red blood cells of their most important functions - the transport of gases and food to all organs and tissues of the animal. In addition, erythrocytes are involved in the regulation of acidbase balance in the body, in the buffer action of blood.

To study the effect of fodder additive "Lysoforte" on the morphological and biochemical parameters of blood in young pigs, it was taken at the beginning and at the end of the experiment, according to the change in its composition, it can be judged on the intermittent exchange of the organism, its protective responses and many other vital indicators of animals (Table 9).

TABLE IX. MORPhOLOGICAL PARAMETERS OF GILT BLOOD, $\overline{\mathbf{X}} \pm \mathbf{S} \overline{\mathbf{x}}$

\begin{tabular}{|c|c|c|c|}
\hline \multirow{2}{*}{ Index } & \multicolumn{3}{|c|}{ Group } \\
\cline { 2 - 4 } & Control & 1 experimental & 2 experimental \\
\hline \multicolumn{3}{|c|}{ At the beginning of the experiment } \\
\hline hemoglobin, g/1 & $94.6 \pm 1.13$ & $94.9 \pm 0.80$ & $94.7 \pm 1.10$ \\
\hline erythrocytes, $10^{12} / 1$ & $6.8 \pm 4.18$ & $6.9 \pm 2.20$ & $6.7 \pm 4.79$ \\
\hline leukocytes, $10^{9} / 1$ & $8.9 \pm 2.69$ & $8.9 \pm 1.45$ & $9.0 \pm 3.20$ \\
\hline \multicolumn{4}{|c|}{ At the end of the experiment } \\
\hline hemoglobin, g/1 & $110.3 \pm 0.46$ & $110.9 \pm 0.34$ & $111.3 \pm 0.47$ \\
\hline erythrocytes, $10^{12} / 1$ & $8.2 \pm 2.48$ & $8.8 \pm 1.54$ & $8.8 \pm 2.80$ \\
\hline leukocytes, $10^{9} / 1$ & $10.2 \pm 0.58$ & $10.8 \pm 0.61$ & $10.9 \pm 0.29$ \\
\hline
\end{tabular}

The amount of hemoglobin in the blood of experienced animals over the period of scientific and economic experience has increased. Thus, in the 2 experimental group hemoglobin in the blood was more by $0.9 \%$ compared to the control and by $0.5 \%$ compared to 1 test group.

At the beginning of the experiment, the erythrocyte content in the blood was practically the same in all experimental groups and amounted to $6.7-6.9 \times 10^{12} / \mathrm{L}$. By the end of the experiment, the number of erythrocytes in the experimental groups was greater than in the control group by $7.3 \%$.

Significant differences in the content of leukocytes in the blood were not detected throughout the experiment, so at the 
end of the experiment the content of leukocytes was 10.2-10.9 x $10 \%$.

An important indicator reflecting the state of the organism of animals and characterizing the effect of nutrition on the biochemical indicators of blood is the concentration of reserve alkalinity, calcium and phosphorus (Table 10).

The content of hemoglobin in the blood is affected by the mineral composition of feed and the quality of the protein of the feed. Alkaline blood reserve is also associated with mineral nutrition. The mineral composition of the blood is not constant and the physiological state of the organism depends on it.

TABLE $X$. BIOCHEMICAL INDICATORS OF GILT BLOOD, $\overline{\mathbf{X}} \pm \mathbf{S} \overline{\mathbf{x}}$

\begin{tabular}{|c|c|c|c|}
\hline \multirow{2}{*}{ Index } & \multicolumn{3}{|c|}{ Group } \\
\hline & control & 1 experimental & 2 experimental \\
\hline \multicolumn{4}{|c|}{ At the beginning of the experiment } \\
\hline Reserve alkali, $\mathrm{mg} \%$ & $464.0 \pm 2.19$ & $466.4 \pm 0.81$ & $465.8 \pm 0.70$ \\
\hline Calcium, $\mathrm{mg} \%$ & $11.9 \pm 1.29$ & $11.9 \pm 2.37$ & $12.0 \pm 1.13$ \\
\hline Phosphorus, $\mathrm{mg} \%$ & $10.8 \pm 3.41$ & $10.8 \pm 3.37$ & $10.9 \pm 3.60$ \\
\hline \multicolumn{4}{|c|}{ At the end of the experiment } \\
\hline Reserve alkali, $\mathrm{mg} \%$ & $548.7 \pm 1.37$ & $563.0 \pm 0.38$ & $574.8 \pm 1.78$ \\
\hline Calcium, $\mathrm{mg} \%$ & $12.4 \pm 1.64$ & $12.5 \pm 2.00$ & $12.5 \pm 1.62$ \\
\hline Phosphorus, $\mathrm{mg} \%$ & $11.0 \pm 2.29$ & $11.1 \pm 2.06$ & $11.1 \pm 3.11$ \\
\hline
\end{tabular}

At the beginning of the main period, the reserve alkali was 464.0-466.4 $\mathrm{mg} \%$. By the end of the main period, the alkaline reserve in the serum of all animals increased by $15.4 \%$ in the control group, by $17.2 \%$ in the control group and by $19 \%$ in the experimental group.

The concentration of calcium and phosphorus in the blood of the experimental animals practically does not change, and then increases toward the end of the experiment. Thus, in the control group, the calcium concentration increased by $4.03 \%$, phosphorus - by 1.8\%; in 1 experimental group - by 4.8 and 2.7, and in 2 experimental groups - 4 and 1.8, respectively.

The level of total protein in the blood serum characterizes the protein supply of animal diets (Table 11).

TABLE XI. CONTENT OF TOTAL PROTEIN AND ITS FRACTIONS, $\overline{\mathbf{X}} \pm \mathbf{S} \overline{\mathbf{x}}$

\begin{tabular}{|c|c|c|c|}
\hline \multirow{2}{*}{ Index } & \multicolumn{3}{|c|}{ Group } \\
\cline { 2 - 4 } & Control & 1 experimental & 2 experimental \\
\hline \multicolumn{4}{|c|}{ At the beginning of the experiment } \\
\hline total protein, $\mathrm{g} / \mathrm{l}$ & $70.7 \pm 0.79$ & $70.8 \pm 0.60$ & $70.9 \pm 0.78$ \\
\hline albumins, \% & $45.3 \pm 1.11$ & $45.3 \pm 1.40$ & $45.5 \pm 0.34$ \\
\hline globulins, \% & $55.9 \pm 0.86$ & $55.1 \pm 0.93$ & $55.2 \pm 0.75$ \\
\hline$\alpha$-globulins, $\%$ & $16.1 \pm 0.38$ & $16.1 \pm 1.15$ & $16.2 \pm 0.92$ \\
\hline ß- globulins, $\%$ & $17.9 \pm 2.48$ & $18.0 \pm 2.52$ & $18.0 \pm 1.86$ \\
\hline$\gamma$-globulins, $\%$ & $21.3 \pm 1.95$ & $21.3 \pm 2.26$ & $21.4 \pm 1.72$ \\
\hline A / G coefficient & $0.8 \pm 1.73$ & $0.8 \pm 2.17$ & $0.8 \pm 0.86$ \\
\hline \multicolumn{4}{|c|}{ At the end of the experiment } \\
\hline total protein, g/1 & $73.6 \pm 0.63$ & $75.4 \pm 0.48$ & $75.2 \pm 0.55$ \\
\hline albumins, \% & $68.5 \pm 1.29$ & $70.4 \pm 1.29$ & $70.1 \pm 0.97$ \\
\hline globulins, \% & $57.7 \pm 0.90$ & $59.4 \pm 0.50$ & $59.3 \pm 0.52$ \\
\hline$\alpha$ - globulins, $\%$ & $16.6 \pm 0.93$ & $16.8 \pm 1.47$ & $16.6 \pm 0.75$ \\
\hline$\beta$ - globulins, $\%$ & $18.1 \pm 2.41$ & $18.8 \pm 1.82$ & $18.7 \pm 1.63$ \\
\hline$\gamma$ - globulins, $\%$ & $22.2 \pm 1.29$ & $22.0 \pm 1.87$ & $22.0 \pm 1.84$ \\
\hline A / G coefficient & $1.19 \pm 1.80$ & $1.19 \pm 2.23$ & $1.18 \pm 0.87$ \\
\hline
\end{tabular}

The qualitative composition of plasma proteins is very diverse. Albumins are synthesized in the liver and are simple proteins containing up to 600 amino acid residues that support the colloid-osmotic pressure of the plasma, and also participate in the transport of various substances.

Entering the digestive tract of the animal, the proteins are digested by digestive juice enzymes to polypeptides and amino acids, the latter are absorbed into the bloodstream and used as a building material for the synthesis of tissue proteins and for the creation of special biological active substances.

The globulin fraction of whey proteins participates in the transport of lipids, estrogens, fat-soluble vitamins. During the period of intensive growth of the animal, a relative decrease in the level of albumins and a corresponding increase in the level of $\alpha$-globulin are noted in the blood.

Based on the analyses performed, it was established that the total protein and protein fractions in all experimental animals were within the physiological norm. This is indicated by a larger content of pigs 1 and 2 of the experimental groups of the total protein in the blood serum, which is 2.4 and $2.2 \%$ than their analogues of the control group. The use of the fodder additive "Lysoforte" increased the content of $\beta$-globulins by 3.9 and $3.3 \%$ in the protein fractions, which indicates a higher resistance of the animal organism to the 1 and 2 experimental groups.

The main task in the feeding of animals is the cultivation of healthy, strong, with a well-developed skeleton, muscle tissue and internal organs of animals. The uniqueness of meat consists in high energy intensity, the balance of the amino acid composition of proteins, the presence of biologically active substances and high digestibility. Therefore, after the fattening of the young pigs, a control slaughter was carried out. For this, 3 heads from each group were selected.

According to the results of control slaughter (Table 12), the slaughter yield for each animal was determined and, on the average, by group, according to the results of the carcass deboning, the output of muscle tissue, fat and bone, took also measurements of the fat and determined the area of the "muscular eye".

TABLE XII. Results of CONTROl Slaughter of Animals, $\overline{\mathbf{X}} \pm \mathbf{S} \overline{\mathbf{x}}$

\begin{tabular}{|l|c|c|c|}
\hline \multirow{2}{*}{\multicolumn{1}{|c|}{ Index }} & \multicolumn{3}{c|}{ Group } \\
\cline { 2 - 4 } & Control & 1 experimental & 2 experimental \\
\hline preloading weight, $\mathrm{kg}$ & $102.0 \pm 0.39$ & $112.0 \pm 0.42$ & $107.3 \pm 0.51$ \\
\hline slaughter weight, kg & $66.5 \pm 1.06$ & $76.7 \pm 0.94$ & $72.57 \pm 1.45$ \\
\hline $\begin{array}{l}\text { weight of internal fat, } \\
\text { kg }\end{array}$ & $1.74 \pm 2.45$ & $1.96 \pm 1.94$ & $1.94 \pm 1.43$ \\
\hline slaughter yield,\% & $65.2 \pm 0.32$ & $68.5 \pm 0.53$ & $67.6 \pm 0.95$ \\
\hline length of carcass, cm & $97.7 \pm 0.37$ & $100.6 \pm 0.35$ & $98.6 \pm 0.35$ \\
\hline $\begin{array}{l}\text { the area of the } \\
\text { "muscular eye", cm }{ }^{2}\end{array}$ & $28.5 \pm 0.42$ & $32.0 \pm 0.15$ & $30.3 \pm 1.04$ \\
\hline $\begin{array}{l}\text { thickness of bacon over } \\
\text { 6-7 thoracic vertebrae, } \\
\text { mm }\end{array}$ & $35.9 \pm 0.97$ & $33.6 \pm 1.30$ & $36.1 \pm 0.57$ \\
\hline
\end{tabular}

Live weight gilts before slaughter in 1 and 2 test groups exceeded the control, respectively, by 9.8 and $5.2 \%$. 
The animals with the largest slaughter weight were 1 of the experimental group $(76.7 \mathrm{~kg})$, which is $15.3 \%$ more than in the control group and $5.7 \%$ in relation to the 1 experimental group.

The main indicator characterizing the slaughtering quality of fattened pigs is the slaughter yield, which due to the inclusion of fat in the rations of the emulsifier increased by 5.1 and 3.4\% in the 1 and 2 test groups compared to the control. Also in 1 experimental group, the largest length of carcass is noted, which has a positive correlation with the meat productivity of pigs and the yield of muscle tissue, and the area of the "muscular eye", in comparison with the control at 2.96 and $12.28 \%$, respectively.

The thickness of the fat over 6-7 thoracic vertebrae did not have significant differences. In the 2 nd test group, this parameter was the maximum and was $36.1 \mathrm{~mm}$, which is more than in the 1 experimental and control groups by 7.4 and $0.6 \%$, respectively.

A direct reflection of the meat productivity of pigs is the quality of the carcass - the ratio of muscular, fatty and bone tissue in it, determined during the boning (Table 13).

TABLE XIII. COMPOSITION OF CARCASSES OF PIGS, $\overline{\mathbf{X}} \pm \mathbf{S} \overline{\mathbf{x}}$

\begin{tabular}{|c|c|c|c|}
\hline \multirow{2}{*}{ Index } & \multicolumn{3}{|c|}{ Group } \\
\cline { 2 - 4 } & Control & 1 experimental & 2 experimental \\
\hline $\begin{array}{c}\text { weight of refrigerated } \\
\text { carcass, } \mathrm{kg}\end{array}$ & $61.38 \pm 1.39$ & $70.22 \pm 0.42$ & $66.01 \pm 0.51$ \\
\hline muscular tissue, $\mathrm{kg}$ & $34.17 \pm 1.67$ & $40.65 \pm 0.71$ & $37.04 \pm 0.83$ \\
\hline adipose tissue, $\mathrm{kg}$ & $18.74 \pm 1.51$ & $20.95 \pm 0.70$ & $20.08 \pm 0.76$ \\
\hline bone tissue, $\mathrm{kg}$ & $8.47 \pm 2.75$ & $8.63 \pm 1.66$ & $8.89 \pm 1.24$ \\
\hline $\begin{array}{c}\text { ratio of tissues to } \\
\text { carcass mass, } \%\end{array}$ & & & \\
\hline muscular & 55.67 & 57.89 & 56.11 \\
\hline fatty & 30.53 & 29.83 & 30.42 \\
\hline bone & 13.80 & 12.29 & 13.47 \\
\hline \multicolumn{2}{|l}{} \\
\end{tabular}

According to the results of the boning, it can be concluded that the carcasses of the pigs of the 1 experimental group were more meaty. The yield of muscle tissue in the carcasses of the animals of this group was $40.65 \mathrm{~kg}$, which is $18.96 \%$ more than in the control group and $9.75 \%$ than in the 2 test group. By the output of adipose tissue, carcasses of pigs 1 of the experimental group were $11.8 \%$ higher than those of the control group. The proportion of bone tissue in animals of all groups was almost the same and amounted to $8.47-8.89 \%$.

The internal organs of animals that provide normal vital activity of the organism play an important role in the ontogenesis process. According to the degree of their development, one can judge the intensity of metabolic processes in the body, therefore, based on the results of animal slaughter, we inspected and weighed internal organs.

When examining the internal organs of the control and test groups, no pathological changes were noted. By weighing the internal organs of the gilt organs, there is no significant reliable difference in their mass between the experimental and control groups.

The heart of piglets is dark red color, of normal consistency. In 1 experimental group, the heart mass was more by $5.7 \%$ compared to the control group. Kidneys are dark brown in color, dense in consistency. The largest mass of kidneys was in 1 test group and was $325 \mathrm{~g}$.

The liver is dark brown, the capsule is smooth, shiny, the edges are sharp. The best development of the liver by weight relative to the control group was in the pigs of the 1 experimental group. The increase in the size of the liver is associated with its intensive participation in the processes of digestion and metabolism [2].

The spleen of the experimental animals was a dark red color, with no visible changes. In the 2nd experimental group, the weight of the spleen was also greater by $5.7 \%$ than in the animals of the control group and by $4.7 \%$ than in the 2 experimental group.

For a more complete understanding of the effect of inclusion of various amounts of fat emulsifier on the quality of slaughter products, the chemical analysis of the longest muscle in the back was performed (Table 14).

TABLE XIV. CHEMICAL COMPOSITION OF THE LONGEST MUSCLE OF THE BACK, $\%(\overline{\mathrm{X}} \pm \mathrm{S} \overline{\mathrm{x}})$

\begin{tabular}{|l|c|c|c|}
\hline \multirow{2}{*}{\multicolumn{1}{|c|}{ Index }} & \multicolumn{3}{c|}{ Group } \\
\cline { 2 - 4 } & Control & 1 experimental & 2 experimental \\
\hline dry matter & $26.39 \pm 0.62$ & $27.72 \pm 0.30$ & $26.58 \pm 0.41$ \\
\hline protein & $17.71 \pm 0.44$ & $19.96 \pm 0.27$ & $18.67 \pm 0.60$ \\
\hline fat & $6.78 \pm 0.44$ & $7.66 \pm 0.33$ & $7.28 \pm 0.70$ \\
\hline ash & $1.09 \pm 0.04$ & $1.14 \pm 0.04$ & $1.13 \pm 0.02$ \\
\hline $\begin{array}{l}\text { caloric content of } 1 \\
\text { kg of meat, MJ }\end{array}$ & 2882 & 3328 & 3161 \\
\hline
\end{tabular}

In the longest back muscle, the animals receiving the bioemulsifier showed a tendency to increase the dry matter content: in 1 experimental group - by 5.04, in 2 experimental by $0.72 \%$ compared to the control.

The greatest amount of protein and fat was contained in the longest muscle of the back of the 1 test group, 19.96 and $7.66 \%$, which was $12.7 \%$ and $12.9 \%$ respectively.

On the content of mineral elements, the difference between groups is insignificant, nevertheless, it should be noted the tendency of an increase in the content of these substances in the longest muscle of the back in the pigs of the experimental groups. As a result of the increase in fat and ash content in the longest muscle, the backs of 1 and 2 test groups increased the caloric content of $1 \mathrm{~kg}$ of meat compared to the control group by 15.5 and $9.7 \%$, respectively.

With the increase in the productivity of pigs, costs and production costs are reduced [11].

An important indicator of the economic efficiency of the application of a particular feed factor is the cost of feed per unit of production (Table 15).

Animals of all groups consumed practically the same amount of EKE with feeds (394.15 - 409.91).

For $1 \mathrm{~kg}$ of gain in body weight, the gum of the control group consumed 5.96 EKE and $555 \mathrm{~g}$ digestible protein, 1 test group - 5.39 and 513, 2 test - 5.73 EKE and $538 \mathrm{~g}$ respectively. 
TABLE XV. FEED CONSUMPTION PER UNIT OF PRODUCTION

\begin{tabular}{|c|c|c|c|}
\hline \multirow{2}{*}{ Index } & \multicolumn{3}{|c|}{ Group } \\
\cline { 2 - 4 } & Control & $\begin{array}{c}1 \\
\text { experimental }\end{array}$ & 2 experimental \\
\hline $\begin{array}{c}\text { it is consumed with } \\
\text { forages: }\end{array}$ & & & \\
\hline EKE & 394.15 & 409.91 & 406.29 \\
\hline digestible protein, $\mathrm{kg}$ & 36.70 & 39.01 & 38.13 \\
\hline weight gain, $\mathrm{kg}$ & 66.1 & 76.1 & 70.9 \\
\hline $\begin{array}{c}\text { on 1 kg of growth is } \\
\text { spent: }\end{array}$ & & & \\
\hline EKE & 5.96 & 5.39 & 5.73 \\
\hline \% to control & 100 & 90.4 & 96.1 \\
\hline digestible protein, $\mathrm{g}$ & 555 & 513 & 538 \\
\hline \% to control & 100 & 92.4 & 96.9 \\
\hline \multicolumn{2}{|c|}{} \\
\hline
\end{tabular}

In the experimental group 1, the feeds of digestible protein were consumed with $6.29 \%$ higher digestible protein than in the control group and $2.3 \%$ as compared to the analogues of the 2 nd test group. Most of all, compared to the control group of the EKE and the digestible protein for production of a unit of production, the youngest pigs fattening the first test group by 9.6 and $7.6 \%$, respectively, were the most saved.

Thus, the inclusion of the "Lysoforte" bioemulsifier in an amount of $0.75 \mathrm{~kg} /$ tonne in the rations of young pigs on fattening contributed to their productivity and feed payment [4].

\section{CONCLUSION}

Decrease in the cost price of livestock products will be more significant if on the basis of high-grade feeding the productivity of animals will increase. Therefore, for livestock enterprises, along with biological assessment, economic analysis, is important.

To calculate the economic efficiency of the use of the "Lysoforte" bioemulsifier in pig rations, the cost of fodders consumed during the growing and fattening period, the feed consumption per $1 \mathrm{~kg}$ of growth in live weight and the cost of growth were determined.

The cost of $1 \mathrm{~kg}$ of live weight gain in pigs 1 of the experimental group decreased by $15 \%$ compared to the control group and by $7.4 \%$ from the 2 experienced, and the profitability increased by 17.4 and $9.4 \%$, respectively.
Despite the increase in production costs associated with the acquisition of this drug, the cost of growth in the live weight of piglets declined due to their more intensive growth. Therefore, to increase the profitability of pork in the rations of young pigs fattening should include a bio-emulsifier "Lysofort" in the amount of $0.75 \mathrm{~kg} /$ ton feed.

\section{References}

[1] A. Aliev,"Secretory function of the liver and lipid nutrition of pigs", Pig breeding, vol. 5, pp. 11-14, 2002.

[2] L.V. Antipova, I.A. Glotova, I.A. Rogov, Methods of research of meat and meat products, Moscow: Kolos, 2004, pp. 321-328.

[3] A.I. Daryn, Peculiarities of the reproduction and cultivation of pigs. Penza: RIO of PSPA, 2004, pp. 187-192.

[4] O.V. Kovaleva, "Efficiency of using a bioemulsifier and multienzyme complex in rations of young pig"», Siberian Research and Design Institute of Animal Husbandry. Tyumen, 2008, pp. 124-129.

[5] O.V. Kovaleva, M.G. Volynkina, I.E. Ivanova,'Use of enzyme additives in rations of dairy cows and pigs»", Chief livestock specialist, vol. 12, pp. 23-29, 2012.

[6] I. Moskutelo, V. Epifanov, V. Nikolaev, "Fat additive in the composition of mixed fodders for sows" Pig breeding, vol. 2, pp. 24-26, 2003.

[7] N. Niyazov, "Energy level in the ration for fattened pigs", Pig breeding, vol. 3, pp. 14-16, 2005.

[8] V.K. Pestis, A.P. Soldatenko, Feeding of farm animals. Minsk Urajai, 2000, pp. 243-249.

[9] F.S. Khaziahmetov, B.G. Shafriyanov, R.A. Gallyamov, Normalized feeding of farm animals, 2rd ed. St. Petersburg: Lan, 2005, pp. 172-173.

[10] I.P. Sheiko, V.S. Smirnov, Pig breeding. Minsk: New knowledge, 2005. pp. 365-368.

[11] R. Shundalayev, "Optimizing the feeding of animals - an internal reserve to improve the profitability of agricultural producers", Pig breeding, vol. 6, pp. 12-14, 2003.

[12] I.P. Sheiko, V.S. Smirnov, Pig breeding. Minsk: New knowledge, 2005, pp. 254-261.

[13] R. Sundali, «"Optimizing feeding animals - an internal reserve for increasing the profitability of farmers", Pig breeding, vol. 6, pp. 12-14, 2003.

[14] V. Engovatov, V. Dobrynin, S. Volodin, V. Geigel, "Biologically active additives in compound feeds for piglets", Pig breeding, vol. 1, pp. 10-13, 2007.

[15] A. Yahin, M. Kirilov, V. Krokhina, A. Abdrafikov, A. Kuznetsov, "Effectiveness of enzyme preparations of firm "Fanfics" in compound feeds for pigs", Pig breeding, vol. 5, pp. 18-19, 2001. 